\title{
Active Entrepreneurship Education and the Impact on Approaches to Learning: Mixed methods evidence from a six-year study into one entrepreneurship educator's classroom.
}

\author{
Vic Curtis - Course Director, Derby Business School, University of Derby \\ Rob Moon - Senior Lecturer in Enterprise and Entrepreneurship, Derby Business School, University \\ of Derby
}

Andy Penaluna - Professor Emeritus, University of Wales Trinity Saint David

\begin{abstract}
Taking an active and experiential approach to teaching is often assumed to be the best way to promote learning. However, the empirical evidence to support this assertion within entrepreneurship education is inconclusive and current practice suggests that delivery within higher education is still quite passive and traditional. This six-year, mixed method study sets out to demonstrate that a more innovative, active, experiential and constructively aligned approach to teaching, learning and assessment within a UK university, final year International Entrepreneurship module aligned to national guidance (QAA, 2012) impacts positively upon the students' deep and surface approaches to learning. Students viewed the module as significantly more active than passive and the level of deep learning was significantly greater than the level of surface learning. Additionally, the more active approach was significantly correlated to an increase in deep learning and a reduction in surface learning. Students highlighted the active teaching approach and the creation of videos for a local company as part of the assignment as a catalyst for a deeper learning approach. The study provides empirical evidence that active entrepreneurship education has a positive impact on student approaches to learning.
\end{abstract}

Keywords: entrepreneurship education, active learning, experiential learning, approaches to learning, deep learning, surface learning

\section{Introduction}

One of the more persistent entrenched beliefs and 'taken for granted' assumptions within entrepreneurship education (EE) is that active, constructivist, experiential learning approaches are better than passive, behaviourist, knowledge-transmission ones, and will result in improved learning and outcomes. This view is expressed in a wide variety of EE literature (Deakins and Freel, 1998; Cope and Watts, 2000; Rae and Carswell, 2000; Rideout and Gray, 2013; Martin et al., 2013; Bae et al., 2014; Lackéus, 2015; Bacigalupo et al., 2016; Morris and Liguori, 2016; Aluthgama-Baduge, 2017; Nabi et al., 2017; Neck and Corbett, 2018; Jones et al., 2019). In their recent review of the impact of entrepreneurship education in higher education, Nabi et al state that "EE ... has a strong bias towards experiential pedagogy" (2017, p.292) whilst Neck and Corbett state that "adult learners engage in active learning to solve real problems in real environments that are relevant to them. The connection to EE is obvious" (2018, p.17).

However, despite the desire that active entrepreneurship education should be preferred, this approach does not appear to be borne out in practice by the evidence of EE as delivered in higher education. Reviews acknowledge that creating a business plan, case studies and lectures are still the dominant pedagogical methods, and that the current situation is still heavily influenced by the more traditional, didactic, passive delivery focusing on knowledge accumulation rather than more active, experiential approaches (Solomon et al., 2002; Pittaway et al., 2009; Mwasalwiba, 2010; Penaluna et al., 2012; Pittaway and Edwards, 2012; Bae et al., 2014). Rideout and Gray (2013) confirm "today's teaching methods are still overly reliant on ... lectures and case studies, with perhaps a few guest speakers 
thrown in" (p.322) although they also suggest "a general consensus is developing that more multifaceted constructivist models work better for certain populations but this is just speculation" (p.348). Pittaway and Edwards conclude "Despite a widespread desire to promote and develop innovative forms of entrepreneurship education, it is quite evident from this study that current educational practice remains fairly traditional" (2012, p.792). Hence, the rhetoric of more active approaches seems to be trumped by the more passive pedagogical reality within current EE delivery, although much of this evidence concentrates on business school contexts (Penaluna and Penaluna, 2009) and USA, UK and European studies (Blenker et al., 2014; van Ewijk, 2018).

Meta-analysis of the wider active learning literature investigated 89 empirical studies comparing experiential versus traditional pedagogies and concluded "students experienced superior learning outcomes when experiential pedagogies were employed" (Burch et al., 2019, p.239). However, none of the studies investigated concerned $\mathrm{EE}$ and the evidence from within the discipline is inconclusive (Pittaway and Cope, 2007; Rideout and Gray, 2013; Bae et al., 2014; Scott et al., 2015; Nabi et al., 2017). These authors call for more research using theory and impact measures from the wider education literature to provide such evidence.

The EE literature also highlights that there is often insufficient pedagogical detail given in EE studies to determine whether a more active or passive teaching approach was taken (Martin et al., 2013; van Ewijk, 2018). Two possible models are suggested to help detail the EE pedagogy employed. The UK Quality Assurance Agency (QAA, 2018) draw on the work of Jamieson (1984) to suggest learning categorizations as either 'about', 'for' or 'through' entrepreneurship, and that these distinctions can help clarify learning and assessment strategies. 'About' courses "draw upon a more traditional pedagogy involving lectures and set texts to explore theoretical underpinnings" (QAA, 2018, p.14) whereas 'for' courses 'focus on creating an enterprising approach, aiming to help students discover what it is to be enterprising, as well as offering insights into being an entrepreneur... [and] are normally delivered via experiential learning" (QAA, 2018, p.18). 'Through' courses "focus on developing the entrepreneurial capabilities of the student and normally involve learning through doing, reflecting on experiences and drawing on theory" (QAA, 2018, p.18). However, mapping or evaluation of learning though the lens of these categories is limited (Kakouris and Liargovas, 2020). Additionally, little consideration is given to the differing roles of the educator, who may at times not deliver teaching (ie pedagogy), but encourage self-directed learning (ie andragogy) or negotiate learning (ie heutagogy). Moreover, moving from dependency on the educator towards autonomy of thought (Bacigalupo et al., 2016), distinctions between pedagogy, andragogy and heutagogy (Jones et al., 2019) enable the educator to facilitate learning in a manner appropriate to the needs of the learner at a given time.

Nabi et al. (2017) offer an alternative approach based on Bechard and Gregoire's (2005) archetypical higher education teaching models of supply, demand and competence. The supply model is a passive, behaviourist approach which highlights the transmission and reproduction of knowledge through lectures and reading, whereas the demand model involves "personalized meaning through participation in terms of exploration, discussion and experimentation" (Nabi et al., 2017, p.279). The competence model focuses on "active problem solving in real life situations" (p.279) and along with the demand model, is a constructivist approach to EE (Löbler, 2006) where "learning involves actively participating in the construction of new understanding" (Nabi et al., 2017, p.280). It can be seen that 'about' courses and the supply model are similar, 'for' courses and the demand model are similar, and 'through' courses and the competence model are similar, although these neglect the nuanced role of the educator. Both QAA (2018) and Nabi et al. (2017) suggest that different models can be combined (eg about-for, supply-demand or demand-competence).

Lackéus (2015) reviewed the wider education literature and its relation to EE, and argues that constructivist education has much in common with the wider progressive education concept (Dewey, 
1938). He also claims that such learning within EE, whether described as constructivist or progressive, promotes deeper learning. Drawing on the work of Vygotsky and colleagues, Lackéus suggests student activity is better than passivity as:

"human activity leads to two main outcomes; "externalization of activity into artifacts" (Miettinen, 2001, p.299) and "internalization of activity and gradual formation of mental actions", i.e. construction of new mental abilities (Arievitch and Haenen, 2005, p.159). Here, [i.e. in EE] externalization is the resulting value creation and internalization is the resulting deep learning." (2015, p.28)

Macht and Ball (2016) also claim that authentic experiential learning-by-doing results in deep learning and supports student learning outcomes. Aluthgama-Baduge suggests "active participation of [EE] students can engage them in a deep learning approach" (2017, p.318) whilst not engaging with this active approach may lead to surface learning. These authors assert that, within EE, deep learning results from more active, experiential, constructivist approaches where the educator has heightened awareness of their differing roles, whilst surface learning will develop from more traditional, passive, behaviourist approaches. However, there has been little empirical research evidence within EE which has measured deep and surface approaches to learning to substantiate this claim. This study aims to investigate whether teaching which results in more active, experiential EE leads to a deeper approach to learning and/or a reduced surface approach to learning for higher education students.

\section{Deep and Surface Approaches to Learning}

The concept of deep and surface approaches to learning derives from the studies of Marton and Saljo (1976a, 1976b) into how students processed information and the levels of understanding which were reached. The authors asked students to read and answer questions on an academic article, but found two qualitatively different approaches dependent upon the student's intention. As Marton and Saljo state:

"the main difference we found in the process of learning concerned whether the students focused on the text itself or on what the text was about: the author's intention, the main point, the conclusion to be drawn" [original emphasis] (1997, p.43).

Those students who focused on the text itself did not try to understand but rather to memorise in preparation for answering the questions - in Marton and Saljo's view "their awareness skated along the surface of the text" (1997, p.44). The students who focused on what the text was about "seemed to see themselves as creators of knowledge who had to use their capabilities to make critical judgements, logical conclusions and come up with their own ideas" (Marton and Saljo, 1997, p.43).

Svensson (1976) focused on how students organized their information as they went about the task rather than the search for meaning in the text (i.e. the 'how' as opposed to the 'what'), although he too found a similar qualitative difference. Entwistle (1997) suggested combining the conclusions from the two studies as surface and deep approaches to learning. Table 1 gives some of the characteristics of surface and deep approaches to learning developed from the literature.

Biggs' 3P model of teaching and learning (Biggs, 1989; 1993) highlights that both student factors and teaching context determine the approach to learning adopted and these will all influence the learning outcomes achieved. The approach a student takes to their learning is not a fixed and immutable characteristic, but is instead dependent on the students' context or their perception of the context (Laurillard, 1979; Ramsden, 2003; Biggs and Tang, 2011). This is demonstrated in practice by Kember et al. (2008) and Moon et al. (2013). So, whilst deep and surface approaches are not characteristics of the student, they are "strongly related to the quality of the student's learning 
outcome" (Prosser and Trigwell, 1999, p.3). Ramsden (2003) maintains that deeper approaches are related to higher quality outcomes, better grades and are more enjoyable whilst surface approaches are dissatisfying for the student and are associated with poorer outcomes.

\section{Surface Approach to Learning}

\section{Deep Approach to Learning}

1. Intention only to complete task requirements through minimal engagement

2. Focus on 'the signs' (e.g. words and sentences of given text)

3. Focus on individual but unrelated parts of task

4. Memorising information and rote learning for assessments which replaces understanding

5. External emphasis and negative feelings

6. Seeing little value or meaning in tasks set

7. Difficulty in making sense of newly presented ideas and applying in other areas

8. Inability to reflect

9. Creating anxiety and low expectations of success

10. Promoting coverage of material over depth with insufficient time to fully engage
1. Intention to understand and construct meaning through appropriate and meaningful engagement

2. Focus on 'what is signified' (e.g. author's overall argument)

3. Relates previous knowledge to new knowledge

4. Relating to other courses and everyday experiences, and looking for underlying principles and meaning

5. Internal emphasis and positive feelings

6. Awareness of developing value creation

7. Ability to apply learning to new situations through experience of 'doing'

8. Ability to reflect

9. Allowing students to make mistakes and learn from them

10. Emphasizing depth of learning over coverage and providing sufficient time to engage

Table 1: Characteristics of Surface and Deep Approaches to Learning

[Source: Developed from Prosser and Trigwell (1999), Richardson (2000), Ramsden (2003), Entwistle (2009) and Biggs and Tang (2011)]

Little research has been conducted on the application of deep and surface learning within EE contexts to investigate any potential relationships between approaches to learning and more or less active pedagogy. Moon et al. (2013) provide limited evidence that more of a deep approach than a surface approach is adopted within two, first year, undergraduate enterprise modules and that more active teaching methods such as live case studies and questioning appeared to be more effective in promoting a deeper learning approach. However, use of lecture slides, whilst the most popular teaching method investigated, tended to lead to more of a surface approach to learning. These results echo the wider education literature (Bligh, 1998). Limitations of Moon et al.'s (2013) study were the cross-sectional approach during a single year, the low number of students and the lack of any associated qualitative data. Van Ewijk (2018) recommends applying the wider education literature in an EE context, so this research focuses on the level of activity experienced, the differences between deep and surface learning and the associations between these variables within a single entrepreneurship education context over several years. The following hypotheses can be anticipated (Biggs and Tang, 2011): 
$\mathrm{H}_{1}$ : There is no significant difference between level of activity experienced and equally distributed levels of passive and active learning

$\mathrm{H}_{2}$ : There is no significant difference between the deep and surface approaches to learning

$\mathrm{H}_{3}$ : There is no significant correlation between the deep approach to learning and the level of activity experienced

$\mathrm{H}_{4}$ : There is no significant correlation between the surface approach to learning and the level of activity experienced

\section{The International Entrepreneurship Educator's Classroom}

Constructively Aligned, Active and Applied

The University of Derby - whose motto is 'Experientia Docet' which translates as 'experience teaches' - is a UK, post-92, higher education institution with a focus on applied, real world learning for its students. International Entrepreneurship is a 20-credit optional module studied by final year, undergraduate Business students. In 2012, the first author took over as module leader and has run the module thereafter, with the second author acting as internal moderator and the third author as external examiner. In consultation, the new module leader moved teaching and assessment towards a more active, experiential and constructivist EE approach as suggested by the QAA (2012). This was based on the module leader's experience of a traditionally delivered entrepreneurship module during his Master of Business Administration studies at another university, the Postgraduate Certificate of Education program on which he was enrolled at the time and running his own consultancy company which conducted extensive international, on the job training. The pragmatic objective of the change was twofold: to get the students to do something, rather than report on what others had done and to promote a deep learning approach.

Following the QAA guidelines (2012), entrepreneurship education was defined within the module as "the development and application of an enterprising mindset and skills in the specific contexts of setting up a new venture, developing and growing an existing business, or designing an entrepreneurial organization" (p.8). The focus was on developing and growing an existing local, small business through international expansion. Additionally, the module was developed to apply the newly implemented University Learning and Teaching Strategy (2012) which called for education which was student focused, challenging, engaged and for application. The principles of constructive alignment (Biggs and Tang, 2011) were also applied so that undertaking the teaching, learning and assessment activities enacted the module learning outcomes. Macht and Ball (2016) suggest constructive alignment leads to deeper learning, especially if active, experiential learning and authentic assessments are adopted.

The module learning outcomes were:

1. Select appropriate models, frameworks and/or theories and justify why they are appropriate to international entrepreneurship

2. Apply appropriate models, frameworks and/or theories within an international entrepreneurship context

3. Critically evaluate the application of these models, frameworks and/or theories and demonstrate your learning through reflection

Assessment

In keeping with the then newly published QAA guidance on enterprise and entrepreneurship education (2012), the module assessment was changed from a text-based essay about international 
entrepreneurship that used past case studies to an active, experiential learning approach that used real life emerging situations. The assignment was based on developing an international market entry strategy for a local small business. The entrepreneur or company owner came in to launch the assignment which allowed them to describe their organization, its products/services and its current markets. This also allowed for an interactive question and answer session with the students about entrepreneurial life. Different local companies were used in each of the six years considered by this research.

The assignment involved the students researching the appropriate market/sector, the competitors and their products/services, and potential regions or countries which the company could enter, and then deciding on the best two countries to enter in their opinion: one inside and one outside the EU. They also had to decide on an appropriate market entry approach and marketing strategy for those countries. Therefore, the students had to select, justify and apply appropriate international entrepreneurship frameworks in a real-life situation, and then reflect on their learning (i.e. enact the learning outcomes). Additionally, the students were given the choice to work on their own, in pairs or in groups of three.

An innovative assessment feature was the required creation of a 10-minute video in which the students explained and justified their country, market entry and marketing strategy decisions. This could be a live video presentation, a screencast, animation or other creative approach taken by the students and was worth 50\% of the module mark. When first introduced in 2013, no other module in the business school had video creation as part of an assignment. This again was in keeping with QAA (2012) guidelines which suggested a move away from written communication towards a wider multimedia approach. The videos were the externalization of activity as artifacts (Lackéus, 2015), and were creating value for others, in this case, the entrepreneurs as the best videos went back to the companies for their use. The internalization of activity was the resulting deep learning which, in this module, was measured.

Students also completed a 1,500 word critical evaluation and reflection report on the process they had undertaken. This accounted for the remaining 50\% of their mark. This allowed them to reflect on their own personal perspective of the assessment and determine where they had failed or found difficulties in the process, and what they could learn for the future.

Teaching

The schedule of sessions for International Entrepreneurship across the 12-week teaching semester is given in Table 2. The weekly curriculum was developed to apply the principles of the QAA guidance (2012), both in terms of themes and delivery. Each of the seven themes to develop entrepreneurial capability were covered at least twice during the semester and entrepreneurial effectiveness was demonstrated through an active learning delivery using authentic, real world activities, innovation and multimedia communication. Using the current QAA (2018) guidelines to classify and map the approach taken for each session: 19\% of the sessions contain elements classified as 'about' entrepreneurship, $47 \%$ as 'for' and $34 \%$ as 'through'. Therefore, $81 \%$ of the teaching and learning activities are more active, experiential and constructivist which exceeds Morris and Liguori's suggestion that "a large percentage (perhaps as much as 60 percent) of the [entrepreneurship] education program should center on experiential learning" (2016, p.xix). 


\begin{tabular}{|c|c|c|c|c|c|c|c|c|}
\hline Week & $\begin{array}{l}\text { Interactive } \\
\text { Lecture Content }\end{array}$ & $\begin{array}{l}\text { Curriculum } \\
\text { Link to QAA } \\
\text { (2012) } \\
\text { Themes }\end{array}$ & $\begin{array}{l}\text { Curriculum } \\
\text { Link to QAA } \\
\text { (2012) } \\
\text { Delivery }\end{array}$ & $\begin{array}{c}\text { About } \\
\text { For } \\
\text { or } \\
\text { Thru }\end{array}$ & $\begin{array}{l}\text { Seminar / } \\
\text { Workshop } \\
\text { Exercises }\end{array}$ & $\begin{array}{l}\text { Curriculum } \\
\text { Link to QAA } \\
\text { (2012) } \\
\text { Themes }\end{array}$ & $\begin{array}{l}\text { Curriculum } \\
\text { Link to QAA } \\
(2012) \\
\text { Delivery }\end{array}$ & $\begin{array}{l}\text { About } \\
\text { For } \\
\text { or } \\
\text { Thru }\end{array}$ \\
\hline 1 & Introduction & All & $\begin{array}{l}\text { Develop student } \\
\text { self-reliance \& } \\
\text { resilience }\end{array}$ & $\mathrm{A} / \mathrm{F} / \mathrm{T}$ & $\begin{array}{l}\text { Reflect on their own } \\
\text { deep \& surface } \\
\text { learning approaches }\end{array}$ & $\begin{array}{l}\text { Reflection and } \\
\text { action }\end{array}$ & $\begin{array}{l}\text { Subjective } \\
\text { experience }\end{array}$ & $\mathrm{A} / \mathrm{F} / \mathrm{T}$ \\
\hline 2 & $\begin{array}{l}\text { Team quiz to } \\
\text { demonstrate what } \\
\text { you know already }\end{array}$ & $\begin{array}{l}\text { Implementation of } \\
\text { ideas through } \\
\text { leadership \& mgmt }\end{array}$ & Active learning & $\mathrm{A} / \mathrm{F} / \mathrm{T}$ & $\begin{array}{l}\text { Evaluate } \\
\text { international market } \\
\text { entry decisions }\end{array}$ & $\begin{array}{l}\text { Opportunity } \\
\text { recognition \& } \\
\text { evaluation }\end{array}$ & & $\mathrm{F}$ \\
\hline 3 & $\begin{array}{l}\text { Impact of } \\
\text { globalization }\end{array}$ & $\begin{array}{l}\text { Communication \& } \\
\text { strategy skills }\end{array}$ & & A & $\begin{array}{l}\text { Critically evaluate } \\
\text { globalization \& } \\
\text { implications }\end{array}$ & $\begin{array}{l}\text { Decision making } \\
\text { w/ critical analysis } \\
\& \text { judgement }\end{array}$ & $\begin{array}{l}\text { Active learning } \\
\text { through } \\
\text { simulated } \\
\text { activities }\end{array}$ & $\mathrm{F}$ \\
\hline 4 & Impact of culture & Interpersonal skills & $\begin{array}{l}\text { Somewhat } \\
\text { passive learning } \\
\text { (though also } \\
\text { using videos, }\end{array}$ & A & $\begin{array}{l}\text { Apply theory to } \\
\text { determine cultural } \\
\text { impact }\end{array}$ & Interpersonal skills & & $\mathrm{F}$ \\
\hline 5 & $\begin{array}{l}\text { Entrepreneurship \& } \\
\text { international } \\
\text { entrepreneurship }\end{array}$ & All & $\begin{array}{l}\text { discussion, } \\
\text { activities \& } \\
\text { interactive } \\
\text { quizzes) }\end{array}$ & $\mathrm{A} / \mathrm{F}$ & $\begin{array}{l}\text { Identify \& present } \\
\text { an entrepreneurial } \\
\text { opportunity }\end{array}$ & $\begin{array}{l}\text { Opportunity } \\
\text { recognition \& } \\
\text { evaluation }\end{array}$ & & $\mathrm{F} / \mathrm{T}$ \\
\hline 6 & $\begin{array}{l}\text { International } \\
\text { market screening \& } \\
\text { selection }\end{array}$ & $\begin{array}{l}\text { Decision making } \\
\text { w/ critical analysis } \\
\& \text { judgement }\end{array}$ & & $\mathrm{F}$ & $\begin{array}{l}\text { Select \& present a } \\
\text { new int'l market for } \\
\text { the opportunity }\end{array}$ & $\begin{array}{l}\text { Decision making } \\
\text { w/ critical analysis } \\
\& \text { judgement }\end{array}$ & $\begin{array}{l}\text { Authentic, real } \\
\text { world activities } \\
\text { through }\end{array}$ & $\mathrm{F} / \mathrm{T}$ \\
\hline 7 & $\begin{array}{l}\text { Assignment launch } \\
\text { by entrepreneur } \\
\text { inc. Q\&A }\end{array}$ & All & $\begin{array}{l}\text { Authentic, real } \\
\text { world activities }\end{array}$ & $\mathrm{F} / \mathrm{T}$ & $\begin{array}{l}\text { Video creation } \\
\text { software \& } \\
\text { techniques }\end{array}$ & $\begin{array}{l}\text { Communication \& } \\
\text { strategy skills }\end{array}$ & $\begin{array}{l}\text { innovation \& } \\
\text { multimedia } \\
\text { communication }\end{array}$ & $\mathrm{F} / \mathrm{T}$ \\
\hline 8 & $\begin{array}{l}\text { International } \\
\text { market entry }\end{array}$ & $\begin{array}{l}\text { Opportunity } \\
\text { recognition \& } \\
\text { evaluation }\end{array}$ & $\begin{array}{l}\text { Somewhat } \\
\text { passive learning } \\
\text { (though also }\end{array}$ & $\mathrm{F}$ & $\begin{array}{l}\text { Create \& present } \\
\text { short practice video } \\
\text { for the int'l market }\end{array}$ & $\begin{array}{l}\text { Creativity \& } \\
\text { innovation }\end{array}$ & & $\mathrm{T}$ \\
\hline
\end{tabular}




\begin{tabular}{|c|c|c|c|c|c|c|c|c|}
\hline 9 & $\begin{array}{l}\text { International } \\
\text { marketing }\end{array}$ & $\begin{array}{l}\text { Creativity \& } \\
\text { innovation }\end{array}$ & $\begin{array}{l}\text { using videos, } \\
\text { discussion, } \\
\text { activities \& } \\
\text { interactive }\end{array}$ & $\mathrm{F}$ & $\begin{array}{l}\text { Discuss formative } \\
\text { feedback given on } \\
\text { practice videos }\end{array}$ & $\begin{array}{l}\text { Reflection \& } \\
\text { action }\end{array}$ & $\begin{array}{l}\text { Personal } \\
\text { perspectives }\end{array}$ & $\mathrm{T}$ \\
\hline 10 & $\begin{array}{l}\text { Entrepreneurial \& } \\
\text { online strategies }\end{array}$ & $\begin{array}{l}\text { Communication \& } \\
\text { strategy skills }\end{array}$ & quizzes) & $\mathrm{F}$ & $\begin{array}{l}\text { Critically evaluate } \\
\text { (i) journal article \& } \\
\text { (ii) academic model }\end{array}$ & $\begin{array}{l}\text { Decision making } \\
\text { w/ critical analysis } \\
\& \text { judgement }\end{array}$ & $\begin{array}{l}\text { Abstract } \\
\text { problems }\end{array}$ & $\mathrm{F} / \mathrm{T}$ \\
\hline 11 & $\begin{array}{l}\text { Financial } \\
\text { implications }\end{array}$ & $\begin{array}{l}\text { Decision making } \\
\text { w/ critical analysis } \\
\& \text { judgement }\end{array}$ & & $\mathrm{F}$ & $\begin{array}{l}\text { Reflect on their own } \\
\text { development inc. } \\
\text { peer feedback }\end{array}$ & $\begin{array}{l}\text { Reflection \& } \\
\text { action }\end{array}$ & $\begin{array}{l}\text { Subjective } \\
\text { experience \& } \\
\text { learn frm failure }\end{array}$ & $\mathrm{T}$ \\
\hline 12 & Summary & All & $\begin{array}{l}\text { Emerging real } \\
\text { world situations }\end{array}$ & $\mathrm{A} / \mathrm{F} / \mathrm{T}$ & $\begin{array}{l}\text { Assignment } \\
\text { workshop, inc. deep } \\
\& \text { surface learning }\end{array}$ & $\begin{array}{l}\text { Implementation of } \\
\text { ideas through } \\
\text { leadership \& mgmt }\end{array}$ & $\begin{array}{l}\text { Authentic } \\
\text { activities with } \\
\text { multimedia }\end{array}$ & $\mathrm{T}$ \\
\hline
\end{tabular}

Table 2: International Entrepreneurship Curriculum Mapping to QAA (2018) 
Applying the classification of Nabi et al (2017), there are elements of a supply model pedagogy (e.g. somewhat passive lectures, critical analysis), demand model pedagogy (e.g. active learning, subjective experience, reflection) and competence model pedagogy (e.g. authentic real word activities,

presentations, multimedia video creation). However, as the majority are constructivist approaches, the module could be described as a predominantly demand-competence hybrid model pedagogy. Mapping the weekly curriculum against both QAA (2018) and Nabi et al. (2017) provides a simple but robust approach to classify EE (van Ewijk, 2018). This also demonstrates the need for the educator to adjust their role in order to facilitate learning in a manner appropriate to the needs of the learner at a given time (Jones et al., 2019)

Timetabling limitations meant that delivery throughout the six-year period under consideration was via weekly two-hour, interactive lectures for all students, typically taking place in a tiered lecture theatre, and then two-hour, smaller group seminars (typically 20-25 students) in traditional classrooms, where the material was applied thorough a variety of active discussions, experiential research exercises and group presentations which were open to tutor and peer review and feedback. The lectures were interactive in that they incorporated videos, activities, questioning, discussion and online polls and quizzes so that the mode of delivery changed every 15-20 minutes which helped maintain the level of student concentration (Bligh, 1998). Additionally, each session started with a review of the activities and formative feedback from the previous seminar to reinforce what had been learned.

The seminars in the early part of the semester were for applying appropriate models and frameworks to the wider international entrepreneurship context. These approaches would be useful when students attempted their assignment. The first session also introduced deep and surface learning to the students. Seminars during the middle of the semester were developed around a formative assessment exercise which used a 'cut-down' version of a previous year's assignment. Thus, students practiced creating presentations and videos in a similar and related context to their assignment which allowed for tutor and peer formative feedback during the sessions (Black and Wiliam, 1998). The latter seminars were for developing their assessment coursework, including the video, and the critical evaluation and reflection report.

\section{Research Methodology}

A convergent, mixed methods research design which combines dominant quantitative and supporting qualitative approaches was adopted for the study (Johnson and Onwuegbuzie, 2004; Creswell and Plano-Clark, 2018). Pragmatically, this used data which was already embedded in the module design. The advantage of mixed methods is that the complementary strengths of each helps to negate the weaknesses of the other, or only using one method (Blenker et al., 2014) and so a more complete understanding of the issue is obtained (Teddlie and Tashakkori, 2003). Hence, it has "the potential to increase the validity, depth, richness and creativity of entrepreneurship education research" (Blenker et al., 2014, p.707).

During the last session of the module, students' deep and surface approaches to learning were measured using the 20-item Revised Two Factor Study Process Questionnaire [R-SPQ-2F] (Biggs et al., 2001). This instrument has 10 statements relating to a deep approach and 10 to a surface approach which students rated as applying to themselves during the module $(1=$ Never/Rarely to $5=$ Always /Almost Always). Items were then summed and averaged. Students were also asked to determine their overall perceived level of activity during the module on a 7-point scale ranging from very passive to very active. This was to provide a simple measure of the students' own perception of the level of activity of their educational context (Laurillard, 1979; Ramsden, 2003). The level of deep or surface learning is thus partially a response to that perceived context. Analysis of these data to review 
hypotheses $\mathrm{H}_{1}$ to $\mathrm{H}_{4}$ was through non-parametric tests as the data obtained was both ordinal and ranked.

Qualitative data, which were used in the study to help explain the quantitative data, were obtained through the open comments of anonymous institutional module evaluation questionnaires which were completed by all students during the last session of the module (Blenker et al., 2014; van Ewijk, 2018). Students were asked what was especially good about the module and what could be improved. The comments were analysed through thematic analysis (Braun and Clarke, 2006) by the first author. The second author reviewed a sample of $50 \%$ of the comments and agreed with the themes developed.

\section{Results and Discussion}

Over the six-year period 2012/13 to 2017/18, 384 students enrolled on the International Entrepreneurship module. Of these students, 172 completed the R-SPQ-2F questionnaires which equates to a response rate of $44.8 \%$. The results and analysis from hypotheses $\mathrm{H}_{1}$ to $\mathrm{H}_{4}$ are given in Table 3.

\begin{tabular}{lcllll}
\hline Hypothesis & N & $\begin{array}{l}\text { Non-parametric } \\
\text { Test }\end{array}$ & Statistic & $\begin{array}{l}\text { Level of } \\
\text { Significance }\end{array}$ & Decision \\
\hline $\begin{array}{l}\mathrm{H}_{1} \text { : Level of activity } \\
\text { equally distributed from } \\
\text { passive to active }\end{array}$ & 172 & Chi square, $\mathrm{X}^{2}$ & $\begin{array}{l}\mathrm{X}^{2}=123.1, \\
\mathrm{df}=6\end{array}$ & $\mathrm{p}<0.01$ & Reject \\
$\begin{array}{l}\mathrm{H}_{2} \text { : No difference in deep } \\
\text { and surface approaches to }\end{array}$ & 172 & $\begin{array}{l}\text { Wilcoxon signed } \\
\text { ranks, } \mathrm{T}^{+}\end{array}$ & $\begin{array}{l}\mathrm{T}^{+}=14061.8, \\
\mathrm{z}=10.79\end{array}$ & $\mathrm{p}<0.01$ & Reject \\
$\begin{array}{l}\text { learning } \\
\mathrm{H}_{3} \text { : No association } \\
\text { between deep learning } \\
\text { and level of activity }\end{array}$ & 172 & $\begin{array}{l}\text { Spearman rank- } \\
\text { order correlation } \\
\text { coefficient, } \mathrm{r}_{\mathrm{s}}\end{array}$ & $\begin{array}{l}\mathrm{r}_{\mathrm{s}}=0.310, \\
\mathrm{t}=4.257\end{array}$ & $\mathrm{p}<0.01$ & Reject \\
$\begin{array}{l}\mathrm{H}_{4} \text { : No association } \\
\text { between surface learning } \\
\text { and level of activity }\end{array}$ & 172 & $\begin{array}{l}\text { Spearman rank- } \\
\text { order correlation } \\
\text { coefficient, } \mathrm{r}_{\mathrm{s}}\end{array}$ & $\begin{array}{l}\mathrm{r}=-2.634 \\
\mathrm{t}=-198,\end{array}$ & $\mathrm{p}<0.01$ & Reject \\
\hline
\end{tabular}

Table 3: Hypotheses Results and Analysis for the International Entrepreneurship Module

The student perceived level of activity was analysed through a chi-square test of the 7-point activity scale. This resulted in a chi square statistic of 123.1 with six degrees of freedom which is significant at the $1 \%$ level. Hence, $\mathrm{H}_{1}$ is rejected and we can conclude that the level of activity was not equally distributed across the activity scale. Out of 172 students, $129(75 \%)$ perceived the module as being more active than neutral or passive. Hence, as the module more closely followed the desired QAA (2018) guidance of learning 'for' and 'through' entrepreneurship rather than the more traditional learning 'about' entrepreneurship, the objective of a more active, experiential pedagogy seems to have been achieved.

During the same six-year period, 181 students completed the module evaluation questionnaire (response rate of $47.1 \%$ ). The themes developed and numbers of comments in each theme are given in Table 4 . The most prominent 'especially good' theme developed was the teaching approach which accounted for $26.6 \%$ of the 173 comments. One student described the module as a "creative way of teaching" whilst two others specifically stated "it's a very active module" and "the seminars are really good as it helps to be more active". However, using a real company for the "unique and challenging 
assessment" and developing skills for the future were also prominent themes (14.5\% and $12.7 \%$ of comments respectively) which require a more active, experiential approach. For example, one student appreciated that they had a "real business to work on and base the assessment on so gives it more of a real-world experience feel". Hence, the active, experiential approach using real life situations (Nabi et al., 2017; QAA, 2018) seems also to have been recognised by the students.

\begin{tabular}{lcc}
\hline Themes: what was especially good about the module? & $\begin{array}{c}\text { No of } \\
\text { Comments }\end{array}$ & $\begin{array}{c}\text { \% of } \\
\text { Comments }\end{array}$ \\
\hline Teaching approach & 46 & $26.6 \%$ \\
Use of a real company in assessment & 25 & $14.5 \%$ \\
Skills good for the future & 22 & $12.7 \%$ \\
Content / knowledge & 20 & $11.6 \%$ \\
Confidence in creating and presenting videos & 14 & $8.1 \%$ \\
Formative exercise and associated feedback & 12 & $6.9 \%$ \\
Others (12 themes) & 34 & $19.7 \%$ \\
Total & 173 & $100.0 \%$ \\
& & \\
\hline Themes: what could be improved about the module? & No of & $\%$ of \\
& Comments & Comments \\
\hline Nothing & 27 & $29.0 \%$ \\
More support and time to practice & 21 & $22.6 \%$ \\
Release assignment earlier & 9 & $9.7 \%$ \\
Others (14 themes) & 36 & $38.7 \%$ \\
Total & 93 & $100.0 \%$ \\
\hline
\end{tabular}

Table 4: Thematic Analysis for the International Entrepreneurship Module

The most prominent 'improvement' theme developed was "nothing" with $29.0 \%$ of the comments. However, the second most prominent theme was around the desire for more support and time to practice with $22.6 \%$ of the responses. This lead to formative video feedback being created for students, including examples from previous assignments (Hattie and Timperley, 2007) and giving additional support on critical evaluation and reflection where exemplars were discussed and short anonymous reflection pieces were written in class for peer and tutor feedback using post-it notes. These constructivist approaches to EE (Löbler, 2006) have been added to the most recent iterations of the module following the research.

The difference between the level of deep and surface learning across the six-year period was analysed through a Wilcoxon signed ranks test for related samples (as deep and surface learning results from the same students were being compared). The level of deep learning was significantly greater than the level of surface learning at the $1 \%$ level. Hence, hypothesis $\mathrm{H}_{2}$ is rejected. This is similar to the results of Moon et al. (2013). The rejection of $\mathrm{H}_{1}$ and $\mathrm{H}_{2}$ demonstrate that the pedagogical aim of providing 
an active EE module which encouraged a deep approach to learning whilst trying to avoid a surface approach appears to have been achieved.

This is exemplified by one student who said the module "encouraged me to work hard and learn to develop my skills" whilst another stated it "engages the class more than I'm used to at uni". Other students also describe the module as "engaging" and mention the "creative assignment" with producing a video for a real company. These attributes seemed to help develop deep learning, as suggested by Lackéus (2015) and Biggs and Tang (2011). One student specifically said "it's easy to get deep into EE" whilst another suggested:

"Overall the module ... was very clear, and developed a classroom scenario where it encouraged personal development and progression. Showed us the different rooms and facilities without giving us the keys to the mansion so to speak"

In order to determine if there is any correlation between deep or surface learning during the International Entrepreneurship module and the perceived level of activity, Spearman rank-order correlation coefficients $r_{s}$ were calculated. In both instances, correlations existed: positive for deep learning and negative for surface learning. These are shown in Figures 1 and 2 . The Spearman correlation coefficient for deep learning and level of activity is 0.310 whilst for surface learning and level of activity, it is -0.198 . Both of these correlations are significant at the $1 \%$ level which means hypotheses $\mathrm{H}_{3}$ and $\mathrm{H}_{4}$ are also rejected. Hence, there is evidence of an association between level of activity and both deep and surface learning (Biggs and Tang, 2011). These results would seem to support the view that a more active, experiential approach to EE, using real world authentic assessment, as suggested by QAA (2018), Nabi et al. (2017), Macht and Ball (2016) and others corresponds to improved learning - in this case, an increased level of deep learning and a reduced level of surface learning. As Lackéus (2015) suggests, the more active, experiential and authentic creation of value for others (i.e. video artifacts for external companies) seems to trigger higher levels of deep learning. However, further research is necessary to establish the degree of causality.

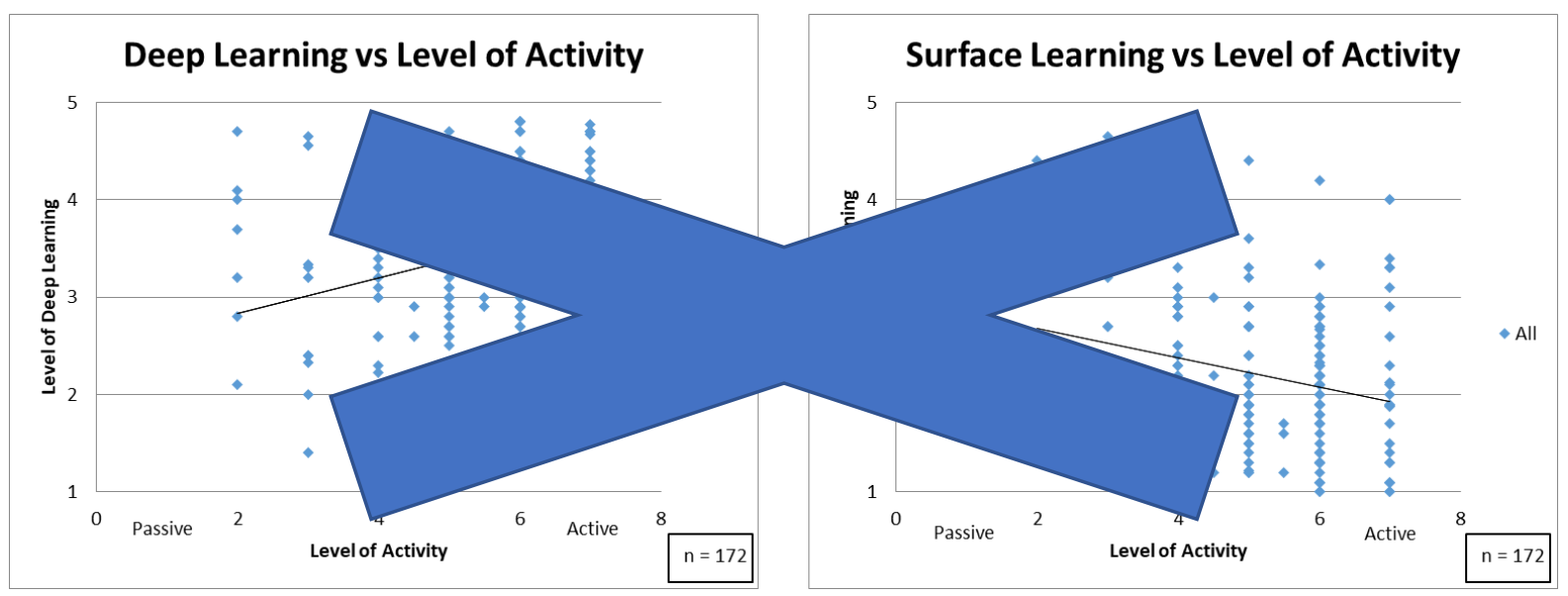

Figure 1: Deep Learning vs Level of Activity

Figure 2: Surface Learning vs Level of Activity

One student described the module as "interesting, interactive and useful" whilst another similarly suggested it was "very interesting, focuses on real world scenarios and applies learning to after uni" and a third thought it taught students "to not only thrive but evaluate opportunities within differing countries". These comments demonstrate the desired combination of developing student interest through doing "an assignment on a real company!", the active, experiential teaching approach and the recognition of the added value of undertaking the module for the student's future were achieved. All these activities help promote deep learning and reduce surface learning, and exemplify the association between level of activity and approaches to learning (Ramsden, 2003, Entwistle 2009; Biggs and Tang, 2011; Lackéus, 2015). 
The adoption of a more active approach seems to have developed deep learning more strongly than reducing surface learning, although both associations being significant at the $1 \%$ level suggests that increased activity has an effect on both reducing surface learning and enhancing deep learning.

Therefore, relatively small increases in activity can help students to start working at a higher cognitive level (Biggs and Tang, 2011). Although evident within this EE context, more research is necessary to determine if this can be extended to other entrepreneurial activities, and indeed to other education contexts in general. For example, different types of students within a module (eg male vs female, higher achieving vs lower achieving, entrepreneurial family background vs non-entrepreneurial family background etc) may perceive the level of activity differently based on their prior knowledge, abilities or expectations (Biggs, 1993). Hence, they may adopt different deep or surface approaches to their learning and any correlations may be different for sub-cohorts within an overall sample. Alternatively, investigations across different types of EE modules (e.g. prescribed vs optional, first year vs final year, undergraduate vs postgraduate, face to face vs online delivery) may reveal different associations based on the maturity of the students, their length of time at the institution, their motivation, their engagement with feedback or their metacognitive or reflective skills (Biggs and Tang, 2011). This knowledge will thus help the entrepreneurship educator take the most appropriate classroom approach for a particular set of students (Jones et al., 2019).

\section{Conclusion}

This mixed methods study of a single entrepreneurship teaching context over a six-year period has four implications for entrepreneurship education practitioners and researchers. Firstly, higher levels of activity have been shown to correlate with an increased deep learning approach and a reduced surface learning approach (Biggs and Tang, 2011). This would imply that adopting the guidance of the QAA (2018), Nabi et al. (2017), Lackéus (2015) and others with regard to taking a more active, experiential approach so that students do not just learn 'about' entrepreneurship but rather learn 'for' and 'through' entrepreneurship would lead to better outcomes and greater impact for students. In this way, they should be able to better apply their learning to other entrepreneurial situations and this should enhance their enterprising skills, attributes, behaviours and competences.

Secondly, analysing and mapping the curriculum through the lens of 'about', 'for' and 'through' entrepreneurship (QAA, 2018) and/or supply, demand or competence models (Nabi et al., 2017) is recommended to EE practitioners as a simple first step to review EE course curriculum in a detailed and comparable way (van Ewijk, 2018). This will allow identification of areas where appropriate, constructively aligned activity can be included (Biggs and Tang, 2011), where the educator needs to adjust their role to facilitate learning (Jones et al., 2019) and will thus aid moving current EE practice beyond the more traditional, passive delivery (Pittaway and Edwards, 2012).

Thirdly, this study has demonstrated that mixed methods research within EE is easily achievable, especially if planned, embedded and conducted within the module curriculum (Blenker et al., 2014; van Ewijk, 2018). Combining quantitative and qualitative aspects through data triangulation can help to explain both 'what works' and how or why this is so. Lastly, as this module was aligned to the initial QAA (2012) guidelines, results were used to inform the development and enhancement of those guidelines (QAA, 2018). Explaining 'what works' in the 'entrepreneurship educator's classroom' can thus benefit the sector and demonstrates the importance of feedback of EE practice into updating and improving policy and theory.

There are limitations within this research, such as the potential self-report bias, non-response bias and the subjective nature of students attributing the level of activity across the module. However, this study provides empirical evidence of how EE has developed student learning through an active teaching approach, the creation of videos for a real company as part of the assignment and the 
development of appropriate future skills. The evidence suggests that an increased level of activity is associated with an increase in deep learning and a reduction in surface learning. Additional research is necessary to further substantiate the strength of these relationships, but it can be seen that active entrepreneurship education does have a positive impact on approaches to learning. 


\section{References}

Aluthgama-Baduge, C.J. (2017) Educating for enterprise: Exploring the role of the teacher. An Interpretative Phenomenological Analysis, Doctoral thesis, Abertay University, UK.

Arievitch, I.M. and Haenen, J.P. (2005) "Connecting sociocultural theory and educational practice: Galperin's approach” Educational Psychologist, 40, 155-165

Bacigalupo, M., Kampylis, P, Punie, Y. and Van den Brande, G. (2016) EntreComp: The Entrepreneurship Competence Framework Luxembourg: Publication Office of the European Union; EUR27939

Bae, T.J., Qian, S., Miao, C. and Fiet, J.O. (2014) “The relationship between entrepreneurship education and entrepreneurial intentions: A meta-analytic review" Entrepreneurship Theory and Practice, 38(2), 217-254

Bechard, J. P., and Gregoire, D. (2005) "Understanding teaching models in entrepreneurship for higher education" In P. Kyro \& C. Carrier (Eds.), The dynamics of learning entrepreneurship in a cross-cultural university context, 104-134, Tampere, Finland: Faculty of Education, University of Tampere

Biggs J.B. (1989) “Approaches to the Enhancement of Tertiary Teaching”, Higher Education Research and Development, 8(1), 7-25

Biggs, J. and Tang, C. (2011) Teaching for Quality Learning at University, $4^{\text {th }}$ Ed, Maidenhead: Open University Press

Biggs, J., Kember, D. and Leung, D.Y.P. (2001) “The revised two factor Study Process Questionnaire", British Journal of Educational Psychology, 71, 133-149

Black P. and Wiliam D. (1998) "Assessment and Classroom Learning”, Assessment in Education: Principles, Policy \& Practice, 5(1), 7-74

Blenker, P., Elmholdt, S.T., Frederiksen, S.H., Korsgaard, S. and Wagner, K. (2014) "Methods in entrepreneurship education research: A review and integrative framework" Education \& Training, 56(8/9), 697-715.

Bligh D. (1998) What's the Use of Lectures? 5th Ed, Bristol: Intellect Books

Braun, V., and Clarke, V. (2006) "Using thematic analysis in psychology" Qualitative Research in Psychology, 3(2), 77-101

Burch, G.F., Giambatista, R., Batchelor, J.H., Burch, J.J., Hoover, J.D., and Heller, N.A. (2019) “A Meta-Analysis of the Relationship Between Experiential Learning and Learning Outcomes" Journal of Innovative Education, 17(3), 239-273

Cope, J. and Watts, G. (2000) "Learning by doing: an exploration of experience, critical incidents and reflection in entrepreneurial learning", International Journal of Entrepreneurial Behaviour \& Research, 6(3), 104-24.

Creswell J.W. and Plano Clark V.L. (2018) Designing and Conducting Mixed Methods Research, $3^{\text {rd }}$ Ed., London: Sage

Deakins, D. and Freel, M. (1998), "Entrepreneurial learning and the growth process in SMEs", The Learning Organization, 5(3), 144-55.

Dewey, J. (1938) Experience and Education New York: Macmillan 
Entwistle N. (1997) “Contrasting Perspectives on Learning” In F. Marton, D. Hounsell and N. Entwistle (Eds.) The Experience of Learning, $2^{\text {nd }}$ Ed., Edinburgh: Scottish Academic Press

Entwistle N. (2009) Teaching for Understanding at University: Deep Approaches and Distinctive Ways of Thinking, Basingstoke: Palgrave MacMillan

Hattie J. and Timperley H. (2007) “The Power of Feedback” Review of Educational Research, 77(1), $81-112$

Jamieson, I. (1984) "Schools and Enterprise". In A. G. Watts \& P. Moran (Eds.), Education for Enterprise, Careers Research and Advisory Centre (CRAC): 19-27. Cambridge: Ballinger.

Johnson R.B. and Onwuegbuzie A.J. (2004) "Mixed Methods Research: A Research Paradigm Whose Time Has Come", Educational Researcher, 33(7), 14-26

Jones C., Penaluna K. and Penaluna A. (2019) "The promise of andragogy, heutagogy and academagogy to enterprise and entrepreneurship pedagogy" Education \& Training, 61(9), 1170-1186

Kakouris A. and Liargovas P. (2020) "On the about/for/through framework of entrepreneurship education: a critical analysis", Entrepreneurship Education and Pedagogy, DOI: $10.1177 / 2515127420916740$

Kember, D., Leung, D.Y.P., and McNaught, C. (2008) "A workshop activity to demonstrate that approaches to learning are influenced by the teaching and learning environment", Active Learning in Higher Education, 9(1), 43-56

Lackéus, M. (2015) Entrepreneurship in Education: What, Why, When, How OECD Entrepreneurship360 Background Paper, Paris: OECD Center for Entrepreneurship Laurillard D. (1979) “The processes of student learning” Higher Education, 8, 395-409

Löbler H. (2006) "Learning entrepreneurship from a constructivist perspective" Technology Analysis \& Strategic Management, 18, 19-38.

Macht S.A. and Ball S. (2016) ““"Authentic Alignment” - a new framework of entrepreneurship education", Education \& Training, 58(9), 926-944

Martin, B.C., McNally, J.J. \& Kay, M.J. (2013) "Examining the formation of human capital in entrepreneurship: A meta-analysis of entrepreneurship education outcomes", Journal of Business Venturing, 28, 211-224.

Marton F. and Saljo R. (1976a) "On qualitative differences in learning: I. Outcome and process, British Journal of Educational Psychology, 46, 4-11

Marton F. and Saljo R. (1976b) "On qualitative differences in learning: II. Outcome as a function of the learner's conception of the task", British Journal of Educational Psychology, 46, 115-127

Marton F. and Saljo R. (1997) “Approaches to Learning” In F. Marton, D. Hounsell and N. Entwistle (Eds.) The Experience of Learning, $2^{\text {nd }}$ Ed., Edinburgh: Scottish Academic Press

Miettinen R. (2001) "Artifact mediation in Dewey and in cultural-historical activity theory", Mind, Culture, and Activity, 8, 297-308.

Moon R.J., Curtis V. and Dupernex S. (2013) "How Enterprise Education Can Encourage Deep Learning to Improve Student Employability?" Industry \& Higher Education, 27(6), 433-448 
Morris, M.H., \& Liguori, E. (2016) "Preface: Teaching reason and the unreasonable" In M.H. Morris \& E. Ligouri (Eds.), Annals of entrepreneurship education and pedagogy, xiv-xxii Northampton, MA: Edward Elgar Publishing

Mwasalwiba, E.S. (2010) "Entrepreneurship education: A review of its objectives, teaching methods and impact indicators" Education \& Training, 52(1), 20-47

Nabi G., Linan F., Fayolle A. Kreuger N. and Walmsley A. (2017) "The Impact of Entrepreneurship Education in Higher Education: A Systematic Review and Research Agenda" Academy of Management Learning \& Education, 16(2), 277-299

Neck H.M. and Corbett, A.C. (2018) "The Scholarship of Teaching and Learning Entrepreneurship", Entrepreneurship Education and Pedagogy, 1(1), 8-41

Penaluna A. and Penaluna K. (2009) "Assessing creativity: drawing from the experience of the UK's creative design educators", Education \& Training, 51(8/9), 718-732

Penaluna K., Penaluna A. and Jones C. (2012) "The context of enterprise education: insights into current practices" Industry \& Higher Education, 26(3), 163-175

Pittaway, L. \& Cope, J. (2007) "Entrepreneurship education. A systematic review of the evidence" International Small Business Journal, 25(5), 479-510

Pittaway L., Hannon P., Gibb A. and Thompson J., (2009) “Assessment Practice in Enterprise Education" International Journal of Entrepreneurial Behaviour and Research, 15(1), 71-93

Pittaway L. and Edwards C. (2012) "Assessment: examining practice in entrepreneurship education" Education \& Training, 54(8/9), 778-800

Prosser M. and Trigwell K. (1999) Understanding Learning and Teaching: The Experience in Higher Education, Buckingham: Open University Press

QAA (2012) Enterprise and entrepreneurship education: Guidance for UK higher education providers [Downloaded from

http://www.qaa.ac.uk/Publications/InformationAndGuidance/Pages/enterprise-entrepreneurshipguidance.aspx on 10/7/13]

QAA (2018) Enterprise and entrepreneurship education: Guidance for UK higher education providers [Downloaded from http://www.qaa.ac.uk/docs/qaas/enhancement-and-

development/enterprise-and-entrpreneurship-education-2018.pdf?sfvrsn=15f1f981_8 on 17/7/18]

Rae, D. and Carswell, M. (2000), "Using a life-story approach in researching entrepreneurial learning: the development of a conceptual model and its implications in the design of learning experiences", Education \& Training, 42(4/5), 220-7.

Ramsden P. (2003) Learning to Teach in Higher Education, $2^{\text {nd }}$ Ed., London: RoutledgeFalmer

Richardson J.T.E. (2000) Researching Student Learning: approaches to studying in campus-based and distance education, Buckingham: Open University Press

Rideout E.C. and Gray D.O. (2013) "Does Entrepreneurship Education Really Work? A Review and Methodological Critique of the Empirical Literature on the Effects of University-Based Entrepreneurship Education" Journal of Small Business Management, 51(3), 329-351

Scott J., Penaluna A. and Thompson J.L. (2015) "A critical perspective on learning outcomes and the effectiveness of experiential approaches in entrepreneurship education: Do we innovate or implement?" Education \& Training, 58(1), 82-93 
Solomon, G.T., S. Duffy, and Tarabishy A. (2002) "The State of Entrepreneurship Education in the United States: A Nationwide Survey and Analysis," International Journal of Entrepreneurship Education 1(1), 65-86

Svensson L. (1976) Study skill and learning, Gothenburg: Acta Universitatis Gothoburgensis

Teddlie C. and Tashakkori A. (2009) Foundations of Mixed Methods Research: Integrating Quantitative and Qualitative Approaches in the Social and Behavioral Sciences, London: Sage

University of Derby (2012) Learning and Teaching Strategy 2012, Derby: University of Derby

Van Ewijk A. (2018) "Persistence and Acuteness of Research Gaps in Entrepreneurship Education: A Systematic Content Analysis of Previous Reviews (1987-2017)", International Journal of Entrepreneurship, 22(2), 1-18 